\title{
PENGEMBANGAN MODUL IPA TERPADU BERBASIS SCAFFOLDING PADA TEMA GERAK UNTUK SISWA KELAS VIII SMP/MTs
}

\author{
Jumaidin Budaeng1), Hena Dian Ayu ${ }^{2}$, Hestiningtyas Yuli Pratiwi ${ }^{3)}$ \\ ${ }^{1,2,3)}$ Program Studi Pendidikan Fisika,Universitas Kanjuruhan Malang, Indonesia
}

\begin{abstract}
This research aims to develop the Integrated Science Module Based on Scene Motion Scaffolding, knowing the quality of Integrated Science module, and evaluate the response of teachers and students of the Integrated Science module. This study is a research and development ( $R \& D$ ) by Borg and Gall modified by Sugiyono. The results of the research module Integrated Science for students developed by subject matter experts and media experts have a quality percentage ofeach $85 \%$ (excellent) and $86.6 \%$ (excellent). While the modules for teachers according to subject matter experts and media experts have quality with the percentage of each $84 \%$ (excellent) and $87 \%$ (very good), the response of teachers to the teachermodule and student module is Strongly Agree with the percentage of each $87.5 \%$ and $89.84 \%$. Of the 10 students of SMP Negeri 3 Kepanjen on a limited test, got the students' response to student IPA module is Strongly Agree with the percentage of $85 \%$. It can be concluded that the Integrated Science Module Based on Scene Motion Scaffolding has met the criteria Very Good quality and fit for use as a teaching material Integrated Science for students of class VIII SMP/MTs.
\end{abstract}

Keywords: Integrated Science Module, Scaffolding, Motion

\begin{abstract}
Abstrak
Penelitian ini bertujuan untuk mengembangkan Modul IPA Terpadu Berbasis Scaffolding pada Tema Gerak, mengetahui kualitas modul IPA Terpadu, dan mengetahui respon guru dan sis wa terhadap modul IPA Terpadu. Penelitian ini merupakan penelitian dan pengembangan (R\&D) menurut Borg dan Gall y ang dimodifikasi oleh Sugiyono. Hasil penelitian modul IPA Terpadu untuk sis wa yang dikembangkan menurut ahli materi dan ahli media memiliki kualitas persentase masing-masing 85\% (sangat baik) dan $86,6 \%$ (sangat baik). Sedangkan modul untuk guru menurut ahli materi dan ahli media memiliki kualitas dengan persentase masing-masing $84 \%$ (sangat baik) dan $87 \%$ (sangat baik), respon guru terhadap modul guru dan modul siswa adalah Sangat Setuju dengan persentase masing-masing 87,5\% dan 89,84\%. Dari 10 siswa SMP Negeri 3 Kepanjen pada uji terbatas, mendapat respon sis wa terhadap modul IPA sis wa adalah Sangat Setuju dengan persentase 85\%. Dengan demikian dapat disimpulkan bahwa Modul IPA Terpadu Berbasis Scaffolding pada Tema Gerak telah memenuhi kriteria kualitas Sangat Baik dan layak digunakan sebagai salah satu bahan ajar IPA Terpadu untuk siswa kelas VIII SMP/MTs.
\end{abstract}

Kata Kunci: Modul IPA Terpadu, Scaffolding, Gerak

DOI : http://dx.doi.org/10.21067/mpej.v1i1.1633

Diterima: Februari 2017; Disetujui: Maret 2017

\section{PENDAHULUAN}

Mata pelajaran IPA untuk jenjang pendidikan tingkat SMP/MTs sederajat

\footnotetext{
* Corresponding Author:

jumaidinmboro@gmail.com
}

yang berlaku saat ini adalah IPA Terpadu, sesuai dengan Peraturan Menteri Pendidikan Nasional (Permendiknas) No. 68 Tahun 2013 tentang Standar Isi pada 
kurikulum 2013 menyatakan substansi Kepanjen, dapat diketahui dari beberapa mata pelajaran IPA di SMP/MTs faktor belum diterapkan pembelajaran IPA merupakan IPA Terpadu, bukan IPA yang secara terpadu antara lain latar belakang terpisah-pisah sebagai mata pelajaran pendidikan guru berasal dari satu bidang fisika, biologi, kimia, bumi dan alam ilmu yang spesifik dan belum ada bahan semesta (Muzari, 2015).

Zuliyati (2014) menyebutkan bahwa jika pembelajaran IPA dilaksanakan secara terpadu dapat membuat pembelajaran menjadi lebih bermakna, dan juga peserta didik mempelajari beberapa Kompetensi Inti (KI) dan Kompetensi Dasar (KD) ajar IPA Terpadu yang terintegrasi (masih memisahkan bidang kajian fisika dan biologi), sehingga menyebabkan guru IPA mengalami cukup kesulitan untuk melakukan pembelajaran IPA secara terpadu (Zuliyati, 2014).

dalam bidang kajian IPA sekaligus tentang makhluk hidup dan proses kehidupan dapat dipadukan dengan kajian IPA tentang materi dan sifatnya. Cara memadukan kedua bidang kajian IPA tersebut dengan menggunakan model keterpaduan tipe shared yaitu pengajaran yang melibatkan dua disiplin ilmu, difokuskan pada konsep yang sama dalam satu tema (Trianto, 2011:6). Melalui pembelajaran ini, siswa dapat secara aktif mencari, menggali, dan menemukan berbagai konsep IPA yang dipelajari secara menyeluruh (holistik), media ajar lain berupa modul. Modul bermakna, autentik, dan aktif (Puskur, adalah bahan ajar yang dirancang secara 2012).

Fakta yang ditemukan di lapangan saat ini, masih banyak sekolah jenjang pembelajaran terkecil dan memungkinkan SMP/MTs yang belum membelajarkan IPA dipelajari secara mandiri dalam satuan secara terpadu (Zuliyati, 2014). Hal ini waktu tertentu agar siswa menguasai sesuai dengan studi pendahuluan yang kompetensi yang diajarkan (Purwanto, dilakukan peneliti di SMP Negeri 3 2007). Penelitian tentang modul sebagai 
bahan ajar telah dilakukan sebelumnya. berhubungan dengan $Z P D$ bahwa Modul dalam pembelajaran IPA kurikulum pembelajaran terjadi apabila siswa bekerja 2013 digunakan sebagai suplemen sumber atau belajar menangani tugas-tugas atau belajar bagi siswa dalam proses belajar masalah kompleks yang masih berada pada secara mandiri (Muhafid, 2013). jangkauan kognitif siswa atau tugas-tugas

Studi pendahuluan yang dilakukan tersebut berada pada daerah perkembangan pada siswa kelas VIII SMP Negeri 3 terdekat (ZPD). Scaffolding merupakan Kepanjen, masih banyak siswa merasa bantuan kepada siswa secara terstruktur kesulitan dalam memahami materi IPA dan pada awal pembelajaran dan kemudian menyelesaikan soal-soal IPA, terlebih pada secara bertahap mengaktifkan siswa belajar materi gerak yang sudah dipelajari mandiri sehingga membuat peserta didik sebelumnya merupakan materi yang lebih memahami materi pelajaran tergolong sulit. Hal ini didukung dengan (Melinda, 2014).

peneliti melakukan tes kemampuan awal Hasil penelitian menunjukkan bahwa yang ditinjau dari ZPD (Zona of Prokximal terdapat peningkatan pemahaman siswa Development) mereka diperoleh hasil tes pada materi ajar dengan menggunakan $65 \%$ siswa rendah. Salah satu penyebab aktivitas scaffolding (Harydi \& Achmadi, kurangnya bantuan yang diberikan oleh 2013). Namun, hal itu cukup sulit untuk guru dalam mengikuti pembelajaran. Hal dilakukan mengingat jumlah siswa yang ini membuktikan bahwa mereka belum perlu dibimbing cukup banyak dapat menguasai konsep IPA dengan baik dibandingkan pendidik. Oleh karena itu (Khusnul, dkk, 2013). Oleh karena itu dibutuhkan sarana pendukung untuk siswa masih memerlukan bantuan berupa mengatasi hal tersebut, sehingga tujuan pendampingan kognitif dalam belajar IPA. pembelajaran dapat tercapai dengan baik Penanggulangan agar seseorang (Harydi \& Achmadi, 2013 dapat sampai pada ZPD yaitu dengan Scaffolding yang diberikan dalam menggunakan scaffolding (Koes, 2012). modul IPA Terpadu berupa penguraian Scaffolding dapat diberikan dengan masalah-masalah ke dalam langkahmemberikan bantuan sehingga hasil belajar langkah pemecahan yang memungkinkan siswa dapat meningkat (Ayu \& Jufriadi, siswa belajar mandiri (Khusnul., dkk, 2013). 2013). Pemberian scaffolding pada modul

Koes (2012) mengatakan scaffolding IPA Terpadu ini diharapkan siswa dapat merupakan pendampingan kognitif yang termotivasi untuk mempelajari materi IPA 
serta dapat menyelesaikan soal dengan pemahaman yang telah dimilikinya, sehingga siswa dapat melewati masa $Z P D$ Nya (Koes, 2012).

Berdasarkan uraian di atas, peneliti bermaksud untuk melakukan penelitian dengan judul 'Pengembangan Modul IPA Terpadu Berbasis Scaffolding Pada Tema Gerak Untuk Siswa Kelas VIII SMP/MTs".

\section{METODE PENELITIAN}

Penelitian ini adalah penelitian dan pengembangan (research and development/R\&D). Menurut Borg dan Gall (1989) penelitian dan pengembangan (research and development/R\&D) merupakan metode penelitian yang digunakan untuk mengembangkan atau memvalidasi produk-produk yang digunakan dalam pendidikan dan pembelajaran. Prosedur penelitian ini menggunakan prosedur penelitian pengembangan menurut Borg \& Gall (1989), dengan lebih sederhana melibatkan 5 (lima) langkah utama sepertti pada kecil.

Gambar 1.

Penelitian ini dilaksanakan di SMP Negeri 3 Kepanjen. Penelitian ini dilakukan mulai bulan November sampai bulan Januari 2017. Subyek penelitian ini adalah dua guru IPA dan 10 siswa kelas VIII-G untuk penggunaa produk pada uji coba skala kecil. Jenis data yang didapatkan adalah data kuantitatif dan kualitatif. Data kuantitatif didapatkan dari penilaian para ahli terhadap modul IPA Terpadu, angket respon guru dan siswa.

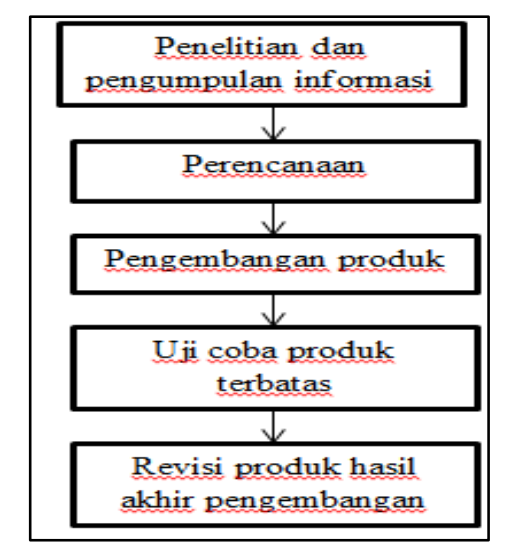

\section{Gambar 1. Bagan langkah-langkah pengembangan model Borg dan Gall} (1989)

Pengumpulan data dalam penelitian ini menggunakan lembar validasi untuk menilai kualitas modul IPA Terpadu dari ahli materi dan media dengan kriteria penilaian modul dinilai mengikuti aturan penetapan yang dimodifikasi dari Setiawan (2014), angket digunakan untuk mengetahui respon guru dan siswa terhadap modul IPA Terpadu pada uji coba skala

\section{HASIL DAN PEMBAHASAN}

\section{Desain Produk}

Hasil penelitian pengembangan yang dilakukan adalah tersusunnya modul IPA Terpadu Berbasis Scaffolding untuk siswa dan guru. Modul IPA Terpadu ini dikembangkan dengan menggunakan 
model perpaduan shared dengan langkah-langkah penyelesaian soal mengambil tema gerak dengan memadukan scaffolding pada latihan mandiri. Tahapan materi-materi IPA yang terdiri dari bidang scaffolding dapat mempermudah siswa fisika dan bidang biologi. Modul berisi dua dalam menjawab persoalan karena pada Kompetensi Dasar (KD) antara lain: (1) tahapan tersebut terdapat penguraian KD 3.1 Memahami gerak lurus, dan masalah ke dalam langkah-langkah pengaruh gaya terhadap gerak berdasarkan pemecahan memungkinkan siswa itu hukum Newton, serta penerapannya pada belajar mandiri.

gerak makhluk hidup dan gerak benda dalam kehidupan sehari-hari, dan (2) KD 4.1 Melakukan penyelidikan tentang gerak, gerak pada makhluk hidup, dan percobaan tentang pengaruh gaya terhadap gerak. Materi yang terkandung dalam modul ini antara lain materi tentang gerak lurus, gaya, hukum Newton, gerak pada tumbuhan, dan gerak pada hewan.

Modul IPA Terpadu berbasis scaffolding untuk siswa disusun dengan memperhatikan Zone of Proximal Development (ZPD) siswa untuk membantu belajar siswa dalam ranah kognitif. Dalam modul dilengkapi dengan kegiatan siswa dengan tahapan scaffolding berisi suatu kegiatan atau tugas yang harus dilakukan oleh siswa untuk mempelajari, menyelidiki, dan memahami suatu konsep yang sedang dipelajari.

Scaffolding yang diberikan pada modul siswa berupa (1) scaffold visual seperti pada item "Coba Pikirkan", item "Sekilas info", dan (2) scaffold uraian

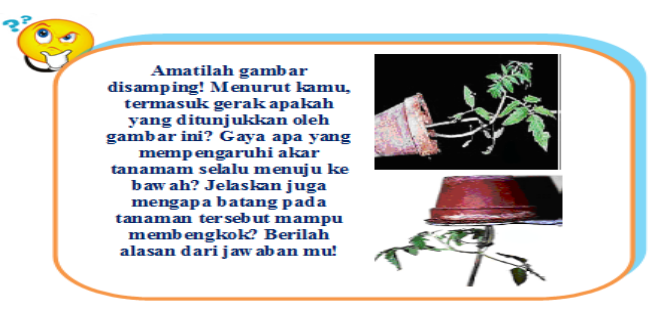

\section{Gambar 2. Scaffold visual pada Item} "Coba Pikirkan"

Berdasarkan Gambar 2., item "Coba Pikirkan" merupakan scaffold visual yang diberikan dalam bentuk tuntunan jawaban berupa pertanyaan arahan, gambar, dan simbol, yang terkandung konsep materi untuk memberikan motivasi siswa sebagai pengetahuan awal dimana terdapat pertanyaan yang berada dikisaran $Z P D$ siswa mengenai materi yang akan dipelajari.

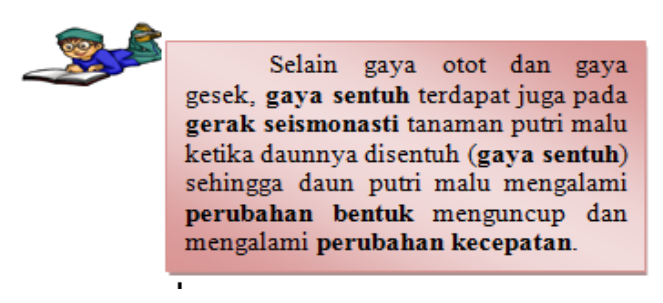

Gambar 3. Scaffold visual pada Item "Sekilas Info"

seperti contoh soal scaffolding, dan 
Sesuai dengan Koes (2012) pemberian scaffolding dapat meningkatkan motivasi pebelajar, karena siswa dapat belajar menangani tugas-tugas atau masalah kompleks yang masih berada pada $Z P D$ siswa.

Berdasarkan Gambar 3., item“ Sekilas Info" merupakan scaffold visual yang menggunakan penyajian konsep secara gabungan verbal dan gambar, sesuai dengan substansi materi yang disampaikan dalam modul untuk mempermudah dan memahami isi materi oleh siswa yang ada dalam kehidupan sehari-hari. Melinda hasil. (2014) mengatakan pemberian scaffolding dapat membangun pemikiran siswa untuk lebih memahami konsep sehingga siswa lebih mudah menyelesaikan permasalahan.

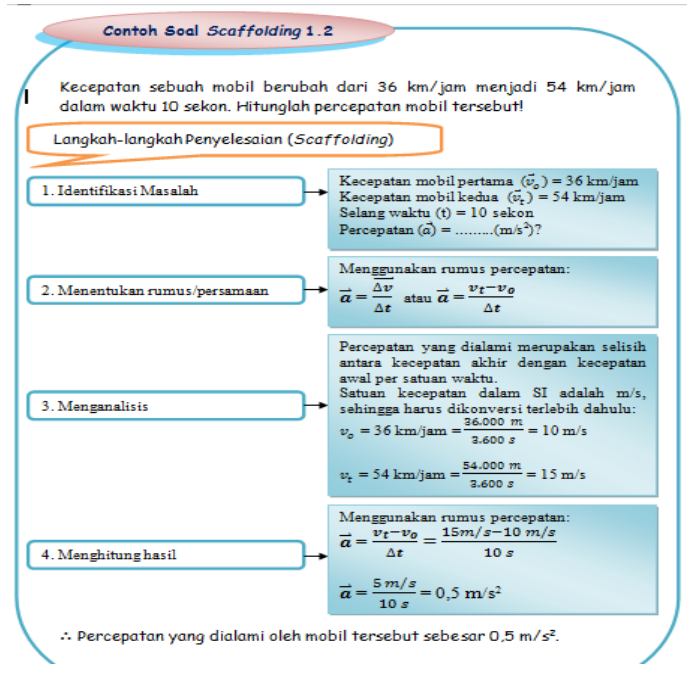

Gambar 4. Scaffold uraian pada item "Contoh Soal Scaffolding"

Berdasarkan Gambar 4., item "contoh soal scaffolding" merupakan scaffold tulisan (uraian) yang terdapat bantuan tahapan-tahapan scaffolding secara verbal, gambar, simbolik, dan matematis agar siswa dapat terbantu untuk memodelkan situasi permasalahan IPA yang dihadapi, menyelesaikan soal-soal latihan, serta mengurangi miss-konsepsi siswa tidak lagi menjadi kesulitan.

Adapun langkah-langkah scaffolding berupa bantuan meliputi identifikasi masalah, isolasi gambar, menentukan rumus atau persamaan (matematis) atau konsep, menganalisis, dan menghitung

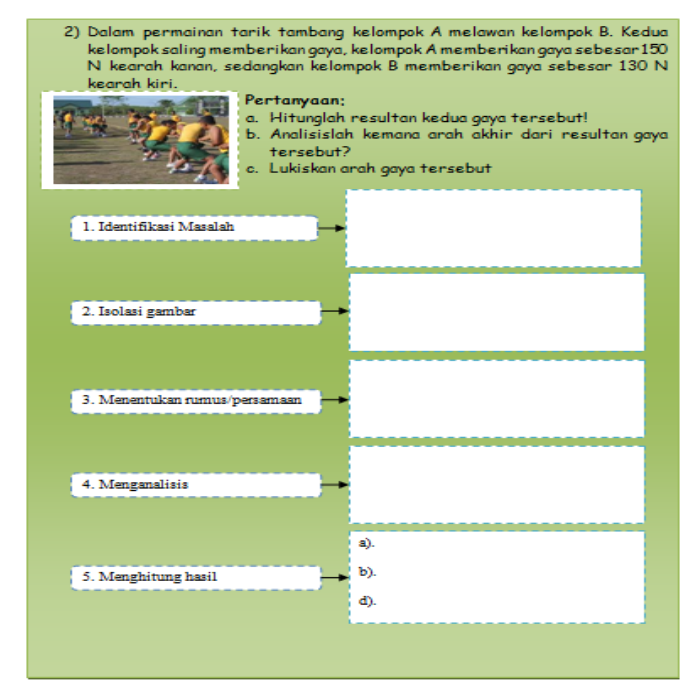

\section{Gambar 5. Item "Latihan Mandiri"}

Berdasarkan Gambar 5., item 'Latihan Mandiri' merupakan aktivitas scaffolding terdapat pengurangan bantuan pada masing-masing tahap penyelesaian. Pengurangan bantuan dilakukan secara terstruktur sehingga lama-kelamaan siswa dapat menyelesaikan permasalahan secara mandiri. Dengan adanya langkah 
scaffolding pada masing-masing sub-bab siswa dapat menyelesaikan permasalahan materi gerak dengan mudah dan tidak lagi menjadi kesulitan untuk dapat menyelesaikan permasalahan tersebut (Harydi \& Achmadi, 2013).

Desain modul IPA Terpadu untuk guru dilengkapi kegiatan guru dengan memberikan scaffolding berisi suatu kegiatan atau tugas yang harus dilakukan oleh guru.

Berdasarkan Gambar 6., dalam modul guru, guru menscaffolding pada saat awal pembelajaran dengan apersepsi, membimbing siswa melakukan praktikum, menyelesaikan tugas atau kegiatan belajar untuk memahami konsep materi menggunakan penyajian konsep secara gabungan verbal, matematis, visual berupa gambar dan simbolik.

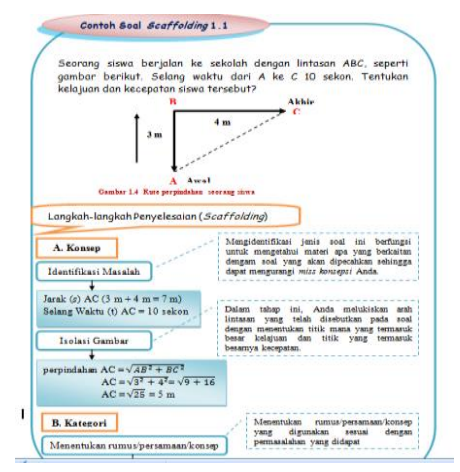

\section{Gambar 6. Aktivitas scaffolding yang diberikan guru pada siswa}

Pemberian scaffolding dalam modul guru diarahkan sesuai dengan tahapannya, agar siswa dapat terbantu untuk penilaian pada aspek tersebut telah menyelesaikan tugas belajar dan soal yang memenuhi komponen kualitas modul. Hal

akan dipecahkan sehingga siswa dapat menguasai materi IPA.

\section{Hasil Validasi}

Modul IPA Terpadu Berbasis Scaffolding untuk siswa divalidasi oleh ahli materi dan ahli media. Berdasarkan ahli materi memiliki kualitas Sangat Baik (SB) dengan persentase $85 \%$ dari skor ideal dan $86,6 \%$ dari ahli media. Penilaian kualitas modul untuk siswa oleh ahli materi dan ahli media sesuai dengan pendapat Setiawan (2014) menyatakan bahwa bahan ajar modul dinyatakan berkualitas apabila semua aspek dalam instrumen penilaian buku teks pelajaran BSNP yang telah dimodifikasi harus mendapat "nilai" sangat baik dari semua aspek.

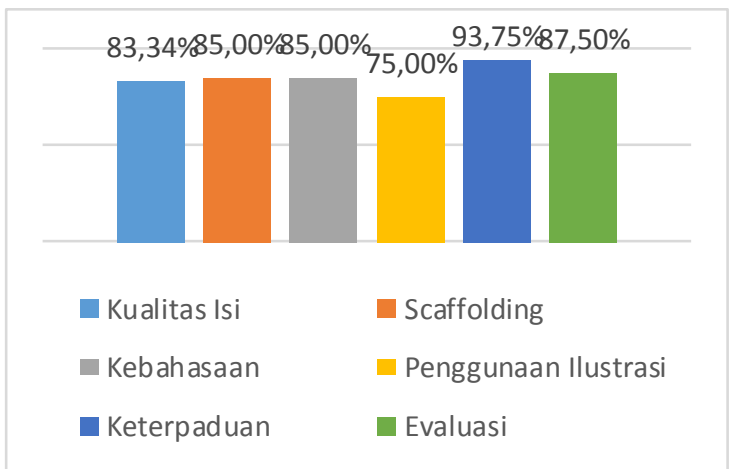

\section{Grafik 1. Persentase tiap aspek pada} modul siswa IPA menurut ahli materi

Berdasarkan Grafik 1., ahli materi memberikan skor tertinggi pada aspek keterpaduan, secara keseluruhan butir-butir 37 
ini sesuai dengan Depdiknas (2008) yang menyatakan pembelajaran IPA Terpadu merupakan pembelajaran yang memadukan pokok bahasan dari bidang kajian IPA (fisika dan biologi) dalam satu bahasan dan dikemas dalam satu tema yang didasarkan pada kecenderungan materi IPA yang memiliki potensi untuk dipadukan dalam satu tema (Trianto, 2011).

Skor terendah dalam penilaian kualitas modul yaitu pada aspek penggunaan ilustrasi dengan persentase hanya $75 \%$. Hal ini terjadi karena rujukan yang dikembangkan kurang termasa dan sumber rujukan yang digunakan masih didominasi buku-buku lama. Santyasa (2009) mengatakan bahwa modul disertai gambar/ilustrasi dapat memperjelas dan mempermudah penyajian pesan agar tidak bersifat verbal.

Saran atau masukan yang diberikan oleh ahli materi adalah perlu diperbanyak keterpaduan IPA, masih banyak materi bersifat fisis. Langkah perbaikan atau revisi yang dilakukan untuk memperbaiki dengan menambah materi keterpaduan IPA biologi pada modul siswa. Berdasarkan Zuliyati (2014) menyebutkan bahwa jika pembelajaran IPA dilaksanakan secara terpadu siswa dapat mempelajari beberapa KI dan KD dalam bidang kajian IPA sekaligus tentang makhluk hidup dengan proses kehidupan dapat dipadukan dengan kajian IPA tentang materi dan sifatnya.

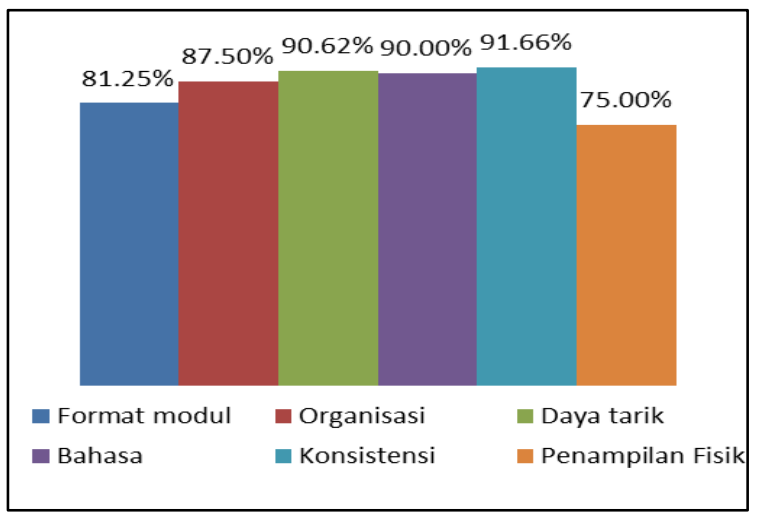

Grafik 2. Persentase tiap aspek pada modul IPA siswa menurut ahli media

Berdasarkan Grafik 2., aspek konsistensi sudah memenuhi kualitas modul. Hal ini sesuai dengan hasil penelitian Ida (2012) mengatakan bahwa penggunaan jenis tulisan dan ukuran huruf yang konsistensi dan jelas akan mempermudah siswa mempelajari bahan ajar modul.

Aspek daya tarik telah memenuhi kualitas modul untuk manambah keminatan siswa dalam mempelajari modul. Hal ini sesuai dengan hasil penelitian Muzari (2015) mengatakan penampilan modul yang menarik dapat mengurangi kebosanan siswa dalam belajar.

Aspek organisasi juga sudah memenuhi kualitas modul dari segi keruntutan materi pelajaran dan pengorganisasian judul dan sub judul dapat membantu siswa belajar sesuai isi. Berdasarkan Daryanto (2013) mengatakan 
siswa akan belajar dalam penyusunan modul lebih terarah dan sistematis.

Skor terendah dalam penilaian kualitas modul yaitu pada aspek penampilan fisik dengan persentase hanya 75\%. Hal ini terjadi karena kurangnya kreativitas penyusun dalam mendesain dan kualitas percetakan modul. Hal ini sesuai dengan penelitian Muzari mengatakan bahwa dengan penampilan modul yang baik dan berkualitas akan menambah daya tarik siswa untuk mempelajari modul sehingga dapat mengurangi kebosanan siswa dalam belajar.

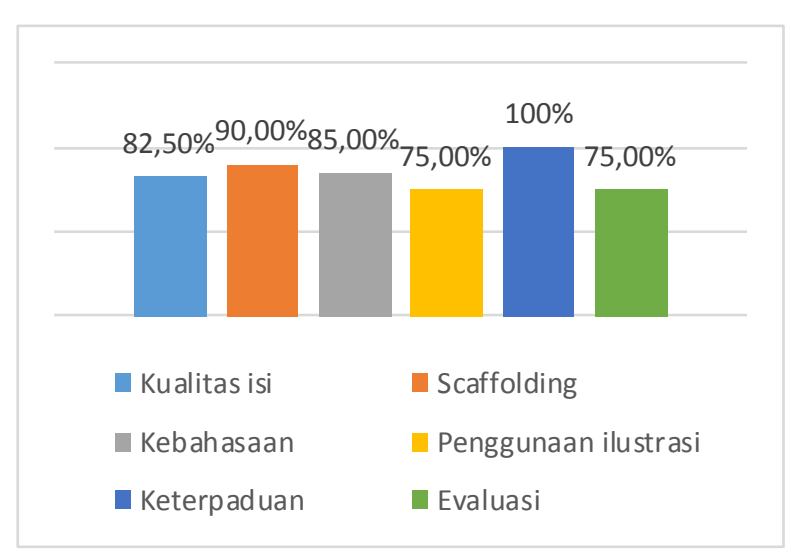

Grafik 3. Persentase tiap aspek pada modul IPA guru menurut ahli materi

Berdasarkan Grafik 3., ahli materi memberikan skor tertinggi pada aspek keterpaduan. Hal ini senada dengan Depdiknas (2008) yang menyatakan pembelajaran IPA Terpadu merupakan pembelajaran yang memadukan pokok bahasan dari bidang kajian IPA (fisika dan biologi) dalam satu bahasan.

Skor tertinggi kedua diperoleh aspek scaffolding dengan persentase sebesar 90\%. Pada aspek tersebut telah memenuhi komponen kualitas modul, seperti kemampuan modul dalam memecahkan persoalan yang diberi bantuan scaffolding, kemampuan kegiatan guru dalam modul membantu penyusunan konsep siswa, kemampuan modul dalam memberi stimulus agar siswa mudah memahami materi dan mengerjakan soal-soal latihan. Hal ini sesuai dengan teori Vygostky (dalam Adinegara, 2010) pembelajaran scaffolding sebagai pemberian sejumlah bantuan kepada seorang anak selama tahaptahap awal pembelajaran pada saat siswa merencanakan, melaksanakan, dan merefleksi tugas-tugas belajarnya.

Skor terendah dalam penilaian kualitas modul yaitu terdapat pada aspek evaluasi dan aspek penggunaan ilustrasi dengan persentase yang sama yaitu $75 \%$. Pada aspek evaluasi, disebabkan masih terdapat beberapa soal evaluasi yang belum sesuai dengan ketercapaian KD dan indikator. Nurhayati (2010) mengatakan bahwa soal evaluasi merupakan alat ukur ketercapaian belajar siswa, sehingga penyusunan soal harus sesuai dengan indikator pencapaian kompetensi.

$\begin{array}{lrr}\text { Aspek } & \text { penggunaan } & \text { ilustrasi } \\ \text { disebabkan } & \text { karena rujukan } & \text { yang } \\ \text { dikembangkan } & \text { kurang termasa dan } & \text { sumber }\end{array}$


rujukan yang digunakan masih didominasi buku-buku paket. Berdasarkan Santyasa (2009) mengatakan bahwa modul disertai gambar/ilustrasi dapat memperjelas dan mempermudah penyajian pesan agar tidak bersifat verbal.

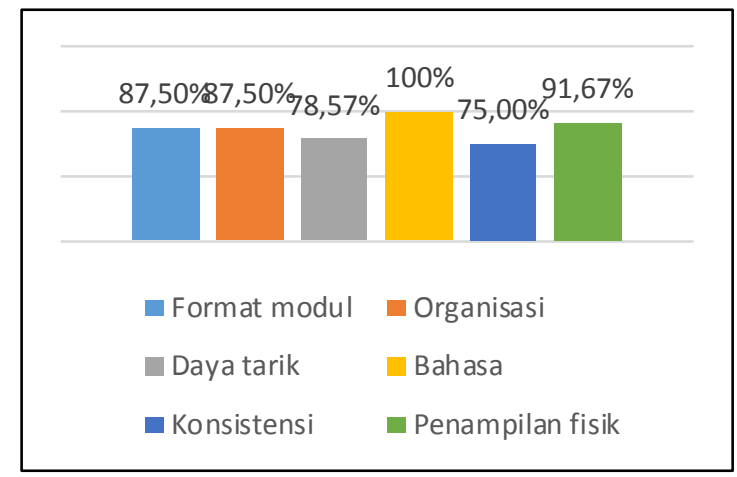

Grafik 4. Persentase tiap aspek pada modul IPA guru menurut ahli media

Saran atau masukan yang diberikan oleh ahli materi adalah beberapa langkah scaffolding perlu dirinci agar siswa lebih mudah memahaminya. Langkah yang dilakukan untuk memperbaiki kualiatas modul dengan menyusun langkah scaffolding lebih rinci. Hal ini sesuai dengan hasil penelitian Melinda (2014) scaffolding merupakan bantuan kepada siswa secara terstruktur pada awal pembelajaran dan kemudian secara bertahap mengaktifkan siswa belajar mandiri sehingga membuat peserta didik lebih memahami materi pelajaran.

Berdasarkan Grafik 4., persentase penilaian yang diberikan ahli media pada aspek bahasa lebih tinggi yaitu $100 \%$. Penggunaan bahasa dalam modul yang dikembangkan telah disesuaikan dengan penggunaan tata bahasa Indonesia. Modul yang dikembangkan menggunakan bahasa yang komunikatif dan mudah dipahami siswa ketika mempelajari modul. Selain itu, simbol dan lambang yang digunakan juga harus konsisten agar tidak membuat siswa bingung dan rancu (Daryanto, 2013).

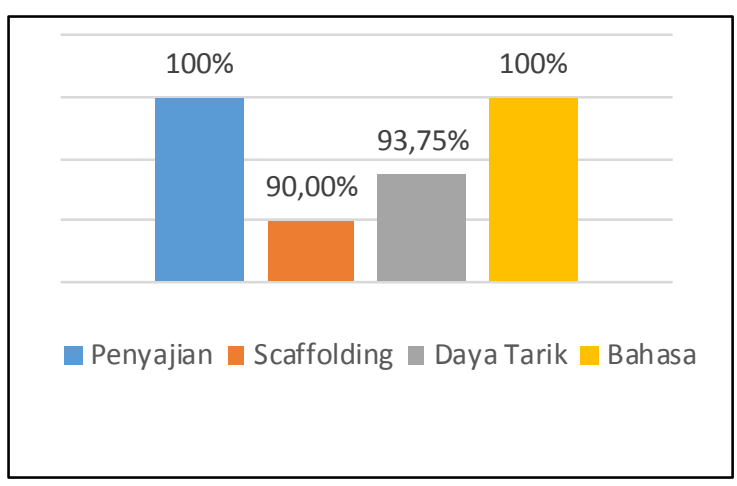

Grafik 5. Persentase tiap aspek respon guru terhadap modul IPA siswa.

Saran atau masukan pertama yang diberikan oleh ahli media adalah sebaiknya tulisan dan batas atas tidak teralalu sempit. Langkah perbaikan atau revisi yang dilakukan untuk memperbaiki kualitas modul dengan memperbaiki tulisan dan batas atas diperlebar. Hal ini sesuai dengan penelitian Ida (2012) yang menyebutkan bahwa penyajian tulisan yang baik akan mempengaruhi pemahaman siswa dalam mempelajari bahan ajar.

Berdasarkan Grafik 5., respon guru yang diberikan pada modul siswa secara keseluruhan semua aspek mendapat respon Sangat Setuju (SS) dengan persentase keidealan $89,84 \%$. Dengan demikian modul siswa dikatakan telah memenuhi 
standar penilaian kualitas modul, karena semua aspek tercantum secara eksplisit (Setiawan, 2014).

Guru IPA memberikan masukan positif mengatakan dengan scaffolding guru dapat mengetahui posisi atau tingkatan siswa. Adinegara (2010) scaffolding merupakan bantuan, dukungan kepada siswa dari guru yang memungkinkan penggunaan fungsi kognitif yang lebih tinggi dan memungkinkan berkembangnya kemampuan belajar sehingga terdapat tingkatan penguasaan materi yang lebih tinggi dari kemampuan dasarnya.

Gambar dan materi disajikan secara terpadu dan tidak terpisah. Hal ini sesuai dengan penelitian Zuliyati menyebutkan bahwa jika pembelajaran IPA dilaksanakan secara terpadu siswa dapat mempelajari materi dalam bidang kajian IPA sekaligus.

Berdasarkan Grafik 6. Respon guru yang diberikan pada modul siswa secara keseluruhan semua aspek mendapat respon Sangat Setuju (SS) dengan persentase keidealan $87,50 \%$. Dengan demikian modul siswa dikatakan telah memenuhi standar penilaian kualitas modul, karena semua aspek tercantum secara eksplisit (Setiawan, 2014). Hasil respon guru IPA menginterpretasikan bahwa modul IPA terpadu dapat menjadi pedoman pembelajaran IPA di sekolah sehingga guru tidak lagi melakukan pembelajaran terpisah-pisah menjadi fisika dan biologi melainkan sudah terpadu menjadi pembelajaran IPA Terpadu. Hal ini sesuai dengan Depdiknas (2008) mengatakan bahwa pembelajaran IPA di SMP/MTs adalah pembelajaran IPA Terpadu agar pembelajaran menjadi lebih bermakna bagi siswa.

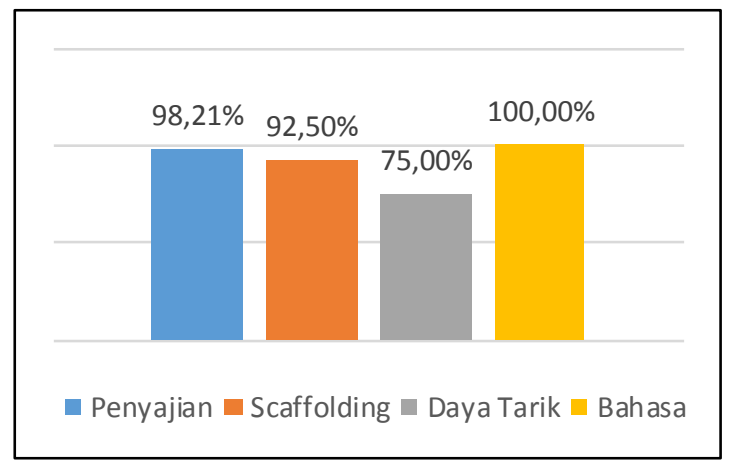

\section{Grafik 6. Persentase tiap aspek respon guru terhadap modul IPA guru}

Guru IPA memberikan masukan positif mengatakan pembelajaran dengan modul IPA sudah membantu guru dalam menjelaskan materi. Sesuai dengan pernyataan Daryanto (2013) mengatakan modul merupakan salah satu bentuk bahan ajar yang dikemas secara utuh dan sistematis untuk membantu guru dan siswa menguasai tujuan belajar yang spesifik.

Angket respon siswa diberikan kepada 10 (sepuluh) siswa SMP N 3 Kepanjen untuk penilaian kualitas modul siswa pada uji coba terbatas. Secara keseluruhan dari semua aspek didapatkan persentase keidealan sebesar $85 \%$. Berdasarkan Grafik 
7., hasil perhitungan ideal, maka modul Prastowo (2012) tujuan penyusunan modul IPA Terpadu untuk siswa yang telah agar siswa dapat belajar secara mandiri dikembangkan menurut siswa tanpa atau dengan bimbingan guru.

dikategorikan sangat setuju. Dengan

Dalam modul siswa terdapat soaldemikian modul siswa dikatakan telah soal dengan tahapan scaffolding dapat memenuhi standar penilaian kualitas modul mempermudah siswa dalam menjawab menurut Setiawan (2014), karena semua persoalan karena pada tahapan tersebut aspek tercantum secara eksplisit.

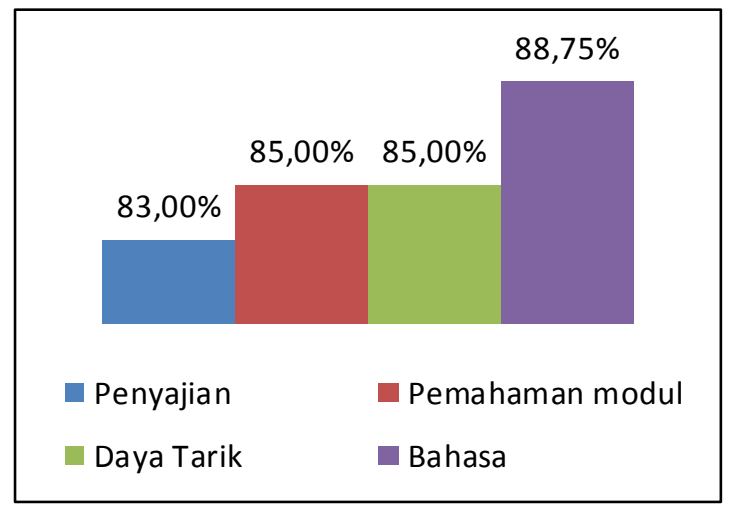

Grafik 7. Persentase tiap aspek respon siswa terhadap modul IPA siswa

Berdasarkan hasil respon siswa diketahui bahwa siswa mengaku tertarik belajar menggunakan modul. Hal ini dikarenakan modul yang dihasilkan memiliki beberapa keunggulan, yaitu sifatnya yang menarik, sajian materi gerak yang mudah dipahami oleh siswa melalui bahasa yang sederhana, dan gambar yang kontekstual dapat mengarahkan siswa memahami uraian materi, dan terdapat penyelesaian soal dengan scaffolding. Modul siswa dikembangkan untuk memudahkan siswa mempelajarinya secara mandiri sehingga siswa menguasai tujuan belajar yang spesifik. Hal ini sesuai dengan terdapat penguraian masalah-masalah ke dalam langkah-langkah pemecahan sehingga memungkinkan siswa belajar mandiri. Hal ini sesuai dengan Adinegara (2010) mengatakan dengan adanya scaffolding dapat membantu siswa dalam menyelesaikan persoalan yang lebih tinggi sehingga siswa tumbuh mandiri.

\section{SIMPULAN}

Simpulan yang dapat diambil dari penelitian pengembangan ini yaitu telah berhasil dikembangkan Modul IPA Terpadu Berbasis Scaffolding pada Tema Gerak untuk Siswa Kelas VIII SMP/MTs yang memenuhi kriteria kualitas sehingga dapat digunakan sebagai bahan ajar IPA. Kualitas Modul IPA Terpadu berbasis scaffolding pada tema gerak untuk siswa dengan kriteria Sangat Baik berdasarkan ahli materi dan ahli media dengan persentase masing-masing sebesar $85 \%$ dan $86,6 \%$. sedangkan kualitas Modul IPA Terpadu berbasis scaffolding pada tema gerak untuk guru dengan kriteria Sangat Baik berdasarkan ahli materi dan ahli 
media dengan persentase masing-masing sebesar $84 \%$ dan $87 \%$.

Modul untuk guru dan siswa juga mendapatkan respon guru dengan persentase masing-masing sebesar $89,84 \%$ dan $87,5 \%$. dan siswa yang sangat setuju. Respon siswa terhadap Modul IPA Berbasis Scaffolding untuk siswa pada uji coba terbatas mendapatkan respon Sangat Setuju (SS) dengan persentase sebesar $85 \%$. Hal ini menunjukkan bahwa modul IPA Terpadu Berbasis Scaffolding pada Tema Gerak untuk siswa dan guru yang dikembangkan mendapat penilaian kriteria "Sangat Baik" dari validator dan dapat diterima siswa dan guru sehingga layak digunakan sebagai bahan ajar IPA Terpadu.

\section{DAFTAR RUJUKAN}

Adinegara. (2010). Vygotskian

Perspective: Proses Scaffolding untuk Mencapai Zone of Proximal Development (ZPD). (online), (http://eprints.uny.ac.id).

Ayu, H.D., \& Jufriadi, A. (2013). Meningkatkan Hasil Belajar Dengan Help Session Bersetting Kooperatif. Erudio. Vol 1 No 2. Hal. 15-25.

Borg, W. R. \& Gall, M. D. (1989). Educational Research: An Introduction. New York: Longman Depdiknas. (2008). Panduan PengembanganPembelajaran IPA secara terpadu. Jakarta. Badan pengembangan dan penelitian Pusat Kurikulum

Daryanto. (2013). Menyusun Modul. Yogyakarta: Gava Media.

Ida, D.A. (2011). Pengembangan Modul Mind Mapping Sel dan Kehidupan Untuk Sekolah Berstandar Internasional. Universitas Negeri Malang. Skipsi tidak diterbitkan.

Hardini, R., \& Pujayanto, E. (2013). Pengembangan Bahan Ajar IPA Terpadu Berbasis Saling Temas Untuk SMP Kelas VIII Dengan Ekosistem Air Tawar. Jurnal Materi dan Pembelajaran Fisika (JMPF) Vol. 3 No. 1 hal 8-15

Harydi, A., \& Achmadi, H.R. (2013). Pengembangan Materi Ajar Berbasis Scaffolding Pada Pokok Bahasan Analisis Vektor di SMAN 1 Waru Pamekasan. Jurnal Inovasi Pendidikan Fisika vol. 02 No. 03 Tahun 2013.

Khotimah, K., Muhardito, \& Suwarsono, P. (2013). Pengembangan Modul Kalor Berbasis Problem Based Learning Berbantuan Paket Scaffolding Untuk Siswa Kelas X SMA. (online),(http://digilib.uns.ac.id).

Koes, H.S. (2012). Pengaruh Strategi Scaffolding-Kooperatif dan Pengetahuan Awal Terhadap 
Prestasi Belajar dan Sikap pada Matakuliah Fisika Dasar. Universitas Negeri Malang: Disertasi tidak diterbitkan.

Melinda. (2014). Strategi Scaffolding Berbasis Multirepresentasi Untuk Mengatasi Kesulitan Pemahaman Konseptual Siswa Dalam Operasi Pecahan Di SMP. (online), (http://repository.uinjkt.ac.id).

Muhafid, E. (2013). Pengembangan Modul IPA Terpadu Berpendekatan Keterampilan Proses pada Tema Bunyi di SMP Kelas VIII. Unnes Science Education Journal, vol 2, No 1 (2013),

(online),

(http://journal.unnes.ac.id/sju/indeks .php/usej).

Muzari, I. (2015). Pengembangan Modul IPA Terpadu Berbasis SETS pada Tema Makanan Sehat dan Tubuhku untuk Meningkat Hasil Belajar. Tesis, (online), Zuliyati, S. (2014). Pengembangan Modul (http://digilib.uns.ac.id).

Nurhayati, A. (2010). Pengaruh Strategi Peta Konsep Terhadap Hasil Belajar Fisika Siswa. (online), (http://repository.uinjkt.ac.id).

Prastowo, A. (2012). Panduan Kreatif Membuat Bahan Ajar Inovatif. Yogyakarta : DIVA press.

Purwanto. (2007). Pengembangan Modul. Jakarta: Depdiknas.
Puskur. (2012). Panduan Pengembangan Pembelajaran IPA Terpadu. Jakarta: Depdiknas. Model IPA Terpadu. pdf, (online),

(www.puskur. net/inc/mdl/050).

Santyasa. (2009). Metode Penelitian Pengembangan dan Teori Pengembangan Modul. Denpasar: FMIPA Universitas Pendidikan Ganesha.

Setiawan, A. (2014). Pengembangan Modul IPA Terpadu Berbasis SainsTeknologi-Masyarakat dengan Tema Pembuatan Kompos sebagai Sarana Berpikir Kreatif Siswa SMP/MTs. Skripsi. (online), (http://digilib.uinsuka.ac.id/id/eprint/13212).

Sugiyono. (2012). Metode Penelitian Kuantitatif Kualitatif dan $R \& D$. Bandung: Alfabeta.

Trianto. (2011). Model Pembelajaran Terpadu. Jakarta: Bumi Aksara.

IPA Terpadu Bermuatan Mind Mapping pada Tema Cahaya dan Penglihatan untuk Kelas VIII SMP/MTS. Unnes Science Education Journal, vol 3, No 1 (2014). 